\title{
Survey process of autolysis from earthworm perionyx excavates obtain protein solution
}

\begin{abstract}
This study aimed to survey the process of procuring protein products from earthworm (Perionyx excavates), with the following results: The activity increased with autolysed time up to 10days, but protein content was only highest in the first day and tend to decrease gradually due to the prolonged autolysis which produced undesirable products. With the optimum conditions of hydrolysis process to collect vermiwash, the study was performed by Design Expert 8.0.6 software to optimize at $55^{\circ} \mathrm{C}$ in 24 hours with $13 \%$ dilution. The process of hydrolysis created twice the amino acid content and the amino acid values were high after normal vermiwash and centrifugation vermiwash. Vermiwash was preserved by $0.2 \%$ potassium sorbate.
\end{abstract}

Volume 3 Issue 3 - 2016
Huynh Ngoc Oanh, Ngo Thi Dieu Lien, Truong Thi Thuy Lien

Hochiminh City University of Technology

Correspondence: Huynh Ngoc Oanh, Hochiminh City University of Technology, Hochiminh City, Vietnam, Tel 0904421602,Email ngocoanh_cnsh@hcmut.edu.vn

Received: November 03, 2015 | Published: February 25, 2016

Keywords: perionyx excavates, vermiwash, design expert, kali sorbate

\section{Introduction}

In the world, especially China, Japan and Korea are very interested in earthworms (Lumbricus and Eisenia fetida).Vietnam also begin examining about some properties of enzymes from earthworm species (Perionyx excavates). ${ }^{1,2}$ The bioactive substances from earthworms so far have not been studied; the scientific evidence of the medicinal use of earthworm species has not been practically proven. ${ }^{3,4}$ In recent years, growing earthworms has developed in the neighborhood of Ho Chi Minh City and some provinces of Mekong Delta. Earthworms are easy to care, prolific, grow fast, and harvested effectively. Especially they have very high protein source (about $68-70 \%$ in dry matter) so this is a valuable source of protein supplement for cattle, poultry, seafood and have been put into industrial farming with various small scale. Project "study the possibility of protein procuring from earthworms and applications to create high protein products" are performed to make the scientific basis for the acquisition of the protein products from the process of autolysis of the earthworm.

\section{Materials and methods}

\section{Materials}

Fresh earthworms (about 8-9weeks) were washed, and weighted about $1 \mathrm{~kg}$ for 500 worms, in the worm farm in Tien Giang. Cu Chi, Ho Chi Minh City

\section{Chemicals and equipments}

Chemicals: Ninhydrin, Folin, $\mathrm{H}_{2} \mathrm{SO}_{4}, \mathrm{HCl}, \mathrm{NaOH}$ standards, $\mathrm{CuSO}_{4}: \mathrm{K}_{2} \mathrm{SO}_{4}(3: 1)$.

Equipments: Kjeldahl systems, Moisture Meter, oven, incubator, water bath, centrifuge.

\section{Experimental methods}

Analytical method

I. Determination of total nitrogen by Kjeldahl method.

II. Determination of protein amine with Ninhydrin method.

\section{Results and discussion}

\section{Surveying the earthworm}

Earthworm has very high water content; dry matter content is only $13-24 \%$ but protein accounts for $45-68 \%$ of dry matter content (Table 1). So this could be a great source of protein to obtain. We surveyed raw materials from different places; and found out there were differences in dry matter content and total initial nitrogen. So earthworm protein content depends on growing conditions, food, season ... In the next study, we will use earthworm sources from Phuong Than farm.

Table I Analysis results of earthworm (*other places)

\begin{tabular}{llll}
\hline Analysis elements & $1 *$ & $2 *$ & $3 *$ \\
\hline $\begin{array}{l}\text { Dry matter content (\% Fresh } \\
\text { weight) }\end{array}$ & $18,81 \pm 1,75$ & $23,11 \pm 1,65$ & $12,90,64$ \\
$\begin{array}{l}\text { Total Nitrogen (\% Dry weight) } \\
4\end{array}$ & $45,7 \pm 3,49$ & $68,02 \pm 0,77$ & $66,4 \pm 0,65$
\end{tabular}

\section{Survey of protease activity of earthworm in autolysis}

The autolysis process increased protein product value due to the intrinsic system of earthworm protease. In our initial study, we examined autolysis process in natural conditions and record edautolysis results over time under the effect of protease earthworm system, and the results given as follows: Protease activity increased through autolysis time, according to Phan Thi Bich Tram, the highest separate activity in 10days, ${ }^{5}$ but the results showed that protein content decreased. So earthworm protease activity in optimal conditions did not collect protein-rich liquid. While fresh earthworms after 10days of autolysis had high protease activity, but smelled because of strong autolysis producing undesirable products, so we will continue to find conditions to obtain useful protein products (Figure 1).

\section{Survey autolysis process produces protein}

Through the preliminary survey results on protease enzyme activity and the results from reference, we performed the optimization process by using Design Expert 8.0 software to consider the interaction among the elements in the process of autolysis 


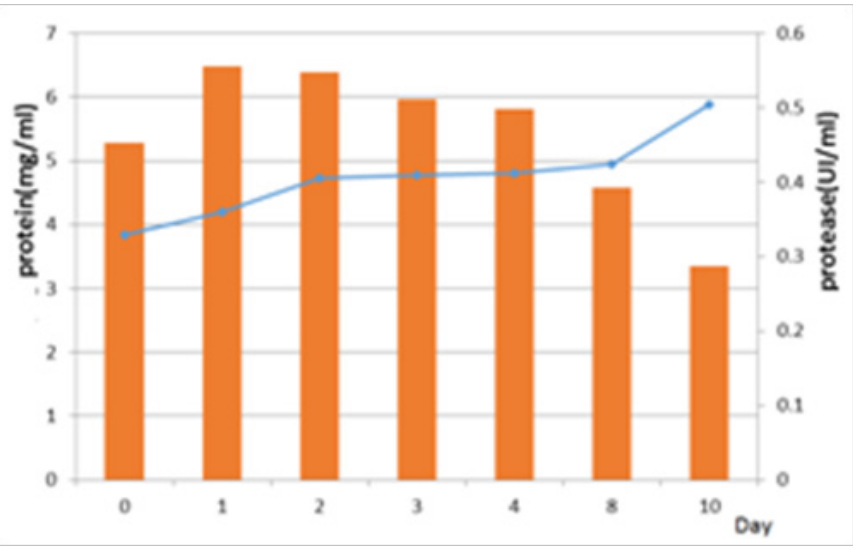

Figure I Protease activities following autolysis time.

Optimizing process to collect vermiwash: In fact, the hydrolysis process does not only depend on individual factors, but is also affected by the interaction of these factors together. Therefore, we conducted experimental planning; choose three of the highest factors affecting protein hydrolysis in earthworm which are temperature, hydrolysis time, and dilution ratio. Earthworm is washed, minced. The autolysis was conducted under the conditions of the planning matrix experiment (dilution ratio calculated by dry weight to calculate how much fresh earthworm to use). Vermiwash used to determine amino nitrogen, thereby calculating the performance results (amino nitrogen/total initial protein) (Figure $2 \& 3$ ).

\begin{tabular}{|c|c|c|c|c|c|c|}
\hline $\begin{array}{l}\text { ఫ్ } \\
\text { फ़ }\end{array}$ & Std & Run & $\begin{array}{c}\text { Factor } 1 \\
\text { A:nhiet do } \\
\text { OC }\end{array}$ & \begin{tabular}{|c|} 
Factor 2 \\
3.ty le pha io \\
$\%$ \\
\end{tabular} & $\begin{array}{c}\text { Factor } 3 \\
\text { C:thoi gian } \\
\text { gio }\end{array}$ & $\begin{array}{c}\text { Response } 1 \\
\text { pieu suat thu. } \\
\%\end{array}$ \\
\hline$\square$ & & 14 & 50.00 & 11.00 & 12.00 & 19.2526 \\
\hline & 2 & 11 & 60.00 & 11.00 & 12.00 & 16.5098 \\
\hline & 3 & 12 & 50.00 & 15.00 & 12.00 & 14.1186 \\
\hline & 4 & 16 & 60.00 & 15.00 & 12.00 & 26.1868 \\
\hline & 5 & 1 & 50.00 & 11.00 & 36.00 & 26.1096 \\
\hline & 6 & 6 & 60.00 & 11.00 & 36.00 & 17.8812 \\
\hline & 7 & 7 & 50.00 & 15.00 & 36.00 & 15.1243 \\
\hline & 8 & 5 & 60.00 & 15.00 & 36.00 & 18.1413 \\
\hline 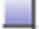 & 9 & 20 & 46.59 & 13.00 & 24.00 & 8.16783 \\
\hline & 10 & 2 & 63.41 & 13.00 & 24.00 & 10.4886 \\
\hline & 11 & 4 & 55.00 & 9.64 & 24.00 & 9.45336 \\
\hline & 12 & 10 & 55.00 & 16.36 & 24.00 & 15.7077 \\
\hline & 13 & 8 & 55.00 & 13.00 & 3.82 & 11.6491 \\
\hline & 14 & 18 & 55.00 & 13.00 & 44.18 & 15.1303 \\
\hline & 15 & 15 & 55.00 & 13.00 & 24.00 & 30.2156 \\
\hline & 16 & 13 & 55.00 & 13.00 & 24.00 & 31.376 \\
\hline & 17 & 19 & 55.00 & 13.00 & 24.00 & 33.6968 \\
\hline & 18 & 17 & 55.00 & 13.00 & 24.00 & 29.0552 \\
\hline & 19 & 9 & 55.00 & 13.00 & 24.00 & 25.5739 \\
\hline & 20 & 3 & 55.00 & 13.00 & 24.00 & 34.8 \\
\hline
\end{tabular}

Figure 2 Performance of autolysis correlates with each conditions.

$Y=-724.1360+22.06352 * A+14.28106 * B+4.19207 * C+0.3257 \mid * A B$ $0.030285 * A C-0.079522 * B C-0.23139 * A^{2}-1.15875 * B^{2}-0.030201 * C^{2}$

Note: Y: Hydrolysis Performance (\%).

A:Temperature; B: Dilution factor; C:Time (hours).

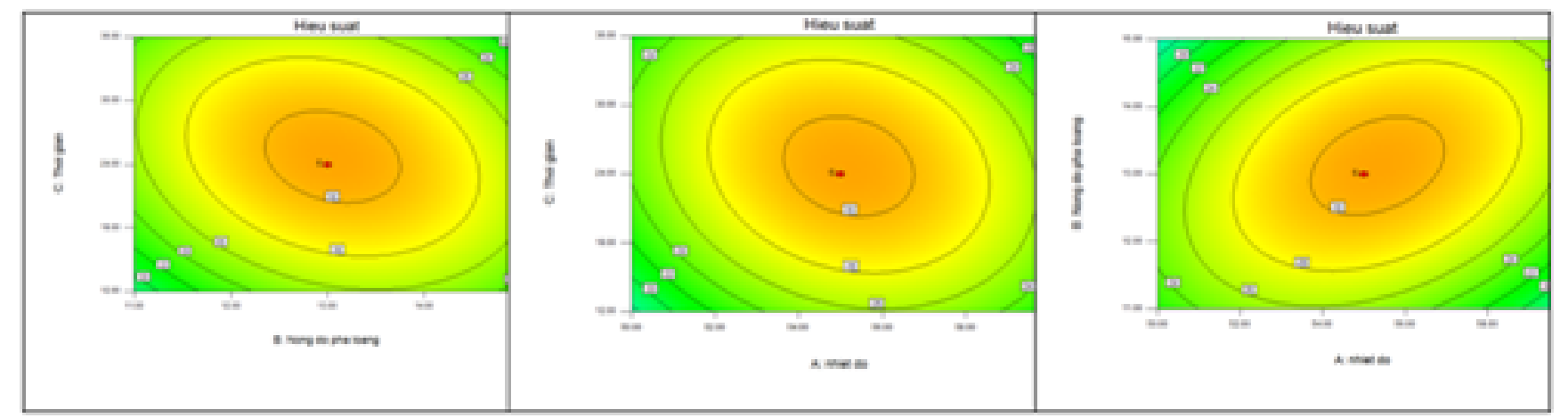

Figure 3 The curve shows relationship between temperature, dilution ratio, time, and hydrolysis performance.

Recognizing the influence of temperature, time, dilution ratio of hydrolysis performance. Using the planning experimental method of Design Expert to optimize the process of autolysis from earthworm, we achieved best performance with conditions $55^{\circ} \mathrm{C}$ during 24 hours with $13 \%$ dilution. Experimental check showed no significant differences between the actual performances hydrolysis obtained (30.8\%) and theory $(30.52 \%)$ in the same conditions. In experiments using fresh earthworms so that when they were dried, not hydrolyzated which decreases activity of the enzyme and reduces costs while drying, easy to apply in practice. In addition, there are some factors such as temperature, dilution ratio, and appropriate time 50-11-36, high performance that we can apply to practical situations to cut down cost.

The products obtained from vermiwash: Autolysis may collect the following products: earthworm solution, vermiwash, after centrifugation vermiwash (Table 2). Hydrolysis doubly increased protein amino and high amino nitrogen value in vermiwash and after centrifugation vermiwash, depending on the purpose of the application; we will have the choice of suitable production plans.

Table 2 Components of protein products obtained from earthworms

\begin{tabular}{|c|c|c|c|c|}
\hline Products & $\begin{array}{l}\text { Nitrogen }(G) / / 00 \mathrm{~g} \\
\text { earthworm }\end{array}$ & $\begin{array}{l}\text { Relative yield } \\
\text { (\%) }\end{array}$ & $\begin{array}{l}\text { Amino acid (G)/ } 100 \mathrm{~g} \\
\text { earthworm }\end{array}$ & $\begin{array}{l}\text { Relative yield } \\
\text { (\%) }\end{array}$ \\
\hline Earthworm solution & 8.67 & 100 & 0.2483 & 48.72 \\
\hline Vermiwash & 7.87 & 90.82 & 0.5096 & 100 \\
\hline $\begin{array}{l}\text { After centrifugation } \\
\text { Vermiwash }\end{array}$ & 6.09 & 70.23 & 0.4966 & 97.45 \\
\hline
\end{tabular}


The process of preservation: Vermiwash were stored at room temperature, we evaluate the overall change in protein, amino nitrogen over time (Figure $4 \& 5$ ).

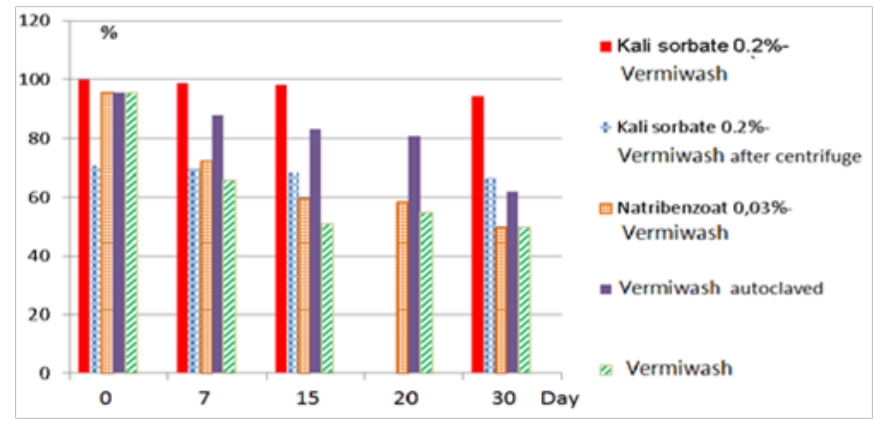

Figure 4 Survey the total protein in vermiwash preservation process.

Reviews: Generally, vermiwash has preservatives. With or without autoclaving, the index of total amino nitrogen content decreased with time. However with potassium sorbate, the preparations are more stable and it is a preservative that commercial products often use.

\section{Comparison of the products from earthworm solution}

To evaluate the quality of the vermiwash product, we have compared some of the products on the market of the Asia and An Phu companies
(Table 3). The survey showed that the Total Nitrogen of vermiwash $(2.235 \mathrm{~g} / 100 \mathrm{ml})$ was higher than the product of Asia Company and An Phu Company (supplemented with algae). On the other hand, amino acid $(0.411 \mathrm{~g} / 100 \mathrm{ml})$ was higher than the earthworm solutions of these companies, so with the above statistics, our results of Nitrogen and Amino acid content were more reasonable than theirs, meanwhile lipid content was alike. Sensorily, vermiwash is pale yellow and has a pleasant scent, while the products of the other companies are smelly, and dark brown. The cause may be due to hydrolysis by the other agents. Vermiwash has been produced and tested at earthworm's Phuong Thanh farm and has obtained good results.

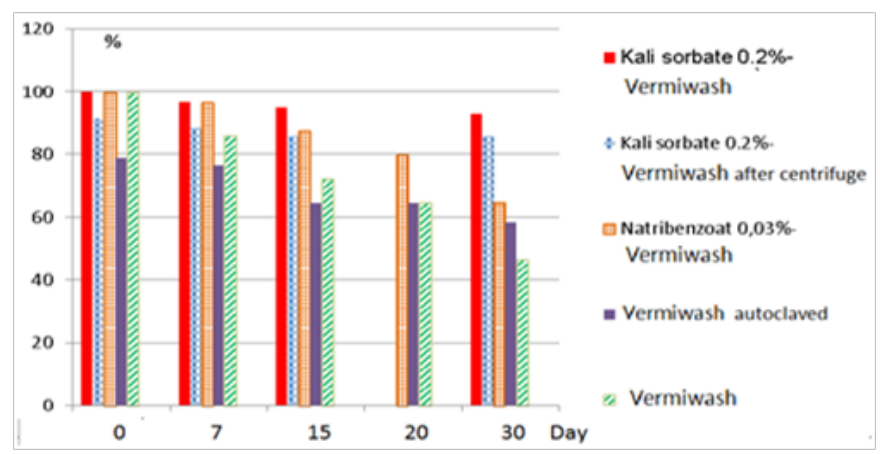

Figure 5 Survey amino acid in vermiwash preservation process.

Table 3 The comparison of the products from earthworm solution

\begin{tabular}{llll}
\hline Sample & Nitrogen $(\mathrm{g} / 100 \mathrm{ml})$ & Amino acid $(\mathrm{g} / 100 \mathrm{ml})$ & Lipid $(\mathrm{g} / 100 \mathrm{ml})$ \\
\hline Vermiwash & $2.235 \mathrm{a}$ & $0.41 \mathrm{la}$ & $7.00 \mathrm{a}$ \\
Earthworm solution of Asia & $1.395 \mathrm{~b}$ & $0.314 \mathrm{~b}$ & $7.05 \mathrm{a}$ \\
Earthworm solution of An Phu & $0.840 \mathrm{c}$ & $0.258 \mathrm{c}$ & $7.05 \mathrm{a}$ \\
\hline
\end{tabular}

The values in the same column with the same letter are different with statistical significance $(p<0.05)$.

\section{Conclusion}

Protease activity increases through autolysis time up to 10days but higher protein content was only the first day and tends to decrease over time due to the prolonged autolysis producing undesired products. Performance Optimization of amino acid solution by Design Expert software was the highest in conditions of $55^{\circ} \mathrm{C}$ for 24 hours with $13 \%$ dilution. Hydrolysis twice increased the amino acid and high amino acid value in vermiwash and centrifugation vermiwash. Vermiwash was preserved by $0.2 \%$ potassium sorbate.

Research shows the ability to diversify products from earthworm, thereby enhancing commercial value of earthworm and contribute to a stable output for livestock of earthworm's farmers today.

\section{Appreciation}

This research is funded by Vietnam National University HoChiMinh City (VNU-HCM) under grant number C2013-20-19. This study aimed to survey the process of procuring protein products from earthworm (Perionyx excavates), with the following results: The activity increased with autolysed time up to 10days, but protein content was only highest in the first day and tend to decrease gradually due to the prolonged autolysis which produced undesirable products. With the optimum conditions of hydrolysis process to collect vermiwash, the study was performed by Design Expert 8.0.6 software to optimize at $55^{\circ} \mathrm{C}$ in 24 hours with $13 \%$ dilution. The process of hydrolysis created twice the amino acid content and the amino acid values were high after normal vermiwash and centrifugation vermiwash. Vermiwash was preserved by $0.2 \%$ potassium sorbate.

\section{Acknowledgements}

None.

\section{Conflict of interest}

The author declares no conflict of interest.

\section{References}

1. Cho IH, Choi ES, Lim HG, et al. Purification and Characterization of Six Fibrinolytic Serine-Proteases. J Biochem Mol Biol. 2004;37(2):199-205.

2. Nakajima N, Mihara H, Sumi H. Characterization of potent fibrinolytic enzymes in earthworm, Lumbricus rubellus. Biosci Biotechnol Biochem. 2000;57(10):1726-1730.

3. Tran Thi Hong Thuy, Nguyen Tran Giang Huong. Some of the pharmacological effects of Dia Long to apply the treatment of hypertension Research. J Pharmacol. 2003;37:325.

4. Thai Tran Bai, Nguyen Van Canh. Issues of using earthworms as drugs of people in Vietnam and Laos. National science conference Report, 2004.

5. Phan Thi Bich Tram. protease system of earthworm Research (Perionyx excavatus) in autolysis and usability. Biochemistry PhD thesis. Vietnam: University of Natural Sciences, National University of Ho Chi Minh; 2010. 